\title{
Become Boyan: The Arrival and Development of Baweanese in Singapore in the 19-20th Century
}

\author{
Mohammad Farihan Aziri, , Ahmad Wahyudi \\ Department of History, Faculty of Humanities, Airlangga University, Indonesia
}

DOI: https://doi.org/10.14710/jmsni.v3i2.6082

\begin{abstract}
This article aimes to discuss the arrival and development of Baweanese people who called Boyan in Singapore in the 19-20th century. Boyan is a term for residents of Bawean Island in Singapore and Malaysia which occurs due to an error pronunciation. Baweanese people since the 19th century has visited Singapore to seek for a job. By using historical method with emphasize on the using primary sources, this research has been successfully reveal the motifs of Baweanese people migrated. In its development, Baweanese people who went to Singapore experienced a change of orientation. At the beginning of the 20th century, they preferred to settle in Singapore. The Baweanese's migration to

Received:

October 10, 2019

\section{Accepted:}

December 9, 2019

Corresponding Author:

farihanade@gmail.com Singapore increased in the early 20th century after the use of steamers as their mode of transportation to go to Singapore. The emergence of mass passenger transportation routes from service agents using steam vessels has an impact on the mobility of Baweanese who migrate to Singapore. KPM's passenger agent is a catalyst for the growth and activity of Baweanese in Singapore. The aim of this stu is to explain when the Bawean people migrated to Singapore as well as the way they moved and settled in Singapore in the mid 19th century until the 20th century.
\end{abstract}

Keywords: Baweanese; Overseas Migration; Steamship.

\section{Introduction}

Bawean Island is one of the islands located in the Java Sea and is administratively included in the Gresik Regency. The island is below the imaginary line, between $5^{\circ} 43^{\prime}$ to $5^{\circ} 52^{\prime}$ south latitude and $112^{\circ} 34^{\prime}$ to $112^{\circ} 44^{\prime}$ east ore, with an area of approximately $200 \mathrm{~km}^{2}$. Formerly, Bawean Island was under the Majapahit empire with the discovery of the Surodakan or Waringin inscription (Priswanto and Wibowo 2017, 128). In the Chinese news reported by Ying-Yai Sheng-Lan, the Majapahit Kingdom had one of the export commodities in the form of pandanus woven. This is in line with the traditional work of the Baweanese as pandanus woven craftsmen. According to De Graff in Heri Priswanto (Utomo 2017, 128), after the collapse of the Majapahit Kingdom, Bawean Island was taken over by the Jepara Kingdom.

In the mid-18th century, Bawean Island underwent a transfer of power from King Madura who had the title Cakraningrat IV from Bangkalan to a trading partner from the Netherlands, namely the Vereenigde Oostindische Compagnie (VOC). When the Dutch colony was under French rule under Luis Napoleon who sent Deandles as the leader of the Colony in the East Indies, Bawean Island was a witness to the Java Sea battle when the British attacked Java. After the British victory captured Java from France, it was soon returned to the Dutch empire which indirectly also affected the status of government in Bawean Island. Administratively, Bawean Island became an area under the Surabaya Resident and in 1920-1965 became an area under the control of Afdeling Gresik (Vredenberg 1991, 14).

The strategic location of Bawean Island influences the maritime route in the archipelago. Many ships leaned for a moment on Bawean Island to fill food and shelter from storms (Utomo 2017, 127). Indirectly, Bawean Island underwent a process of cultural assimilation from various ethnic groups in the archipelago as a result of the opening of the ship's dock on this island. Bawean 
Island was inhabited by several ethnic groups. Some of them are Java, Madura, Bugis, and Palembang.

The majority of Baweanese wee Muslim. The process of Islamization on Bawean Island was introduced by Said Maulana Umar Mas'od in 1350 who came from Madura after defeating Raja $B a b i$ (Vredenberg 1991, 14). After that, Islam developed into the majority religion adopted by the Baweanese. The values of Islam have become part of the lives of the Baweanese. In the 18-19th century, the Baweanese had made the pilgrimage to Mecca. According to historical data, there were approximately 75 and 100 pilgrims went to Mecca and 35,000 inhabitants in 1874, around 1,000 pilgrims, including several women (Dobbin 1991, 123). The main reason that triggers the enthusiasm of Baweanese to perform the pilgrimage was related to the magical religious factor, where after performing the pilgrimage the hope will be blessed.

They gained Islamic knowledge when they went overseas to search for religious knowledge which would later be taught again at Bawean. During the pilgrimage season, the Baweanese go to the holy land by boat. They stopped for a while in Singapore to find work to earn money for continuing the journey to the holy land. In line with this realitySnouck Horgonje said, "Hundreds of people from Bawean Island work as trainers, guards, and others. They save the money to return to their countries (Vredenberg 1962,137). After couple of times when the Baweanese finished their pilgrimage, they returned to Bawean Island and told the story of their journey. The main occupation of Baweanese was as farmer, but also not infrequently some work as fishermen and also pandanus woven craftsmen who are sent to other areas in several places. Baweanese outside are known as traders. In the decade 19-20 century, the Baweanese were known as one of the successful traders in several regions. Baweanese were known to be resilient in trading and they also have relationships with various parties, especially the Chinese and Europeans (Dobbin 1991, 119). In addition to expertise in trade, the Bawean community was also known as a group of people who have a migrant culture. Their main motive for overseas travel cannot be separated from economic problems and other reasons were seeking experience. Baweanese can be found in various regions throughout Southeast Asia. Apart from Singapore and Malaysia, Baweanese were also found in Bangkok, Saigon, Cambodia and Christmas Island regions of Australia (Vredenberg 1964, 116). There were many motives that motivate them to do diaspora in Southeast Asia, one of the main reason was the occupation. In other regions, such as Saigon, Baweanese have reasons to perform the Hajj pilgrimage to Mecca, while in Thailand and Cambodia they worked as European laborers to be employed as plantation workers.

In Singapore, Baweanese were called Boyans. The terminology arose due to the pronunciation mistakes by Europeans in Singapore. Native Baweanese people call themselves Bawean or Babian people (Rahman and Marsita, "The Baweanese"). Because Europeans have authority over Singapore, Boyan's pronunciation continues to be used to refer to Baweanese. The pronunciation also applies to Baweanese who choose to settle in other destinations. In the end, the naming of "Boyan" has become an affirmation of identity for Baweanese. Boyanese in Singapore worked for others (their boss).

Bawean people has been widely studied by some scholars, one of them Vredenberg (1991). He explained various kinds that occur in Bawean society, starting from daily life, religion, and tradition. Looking at his background who is an anthropologist, in his comprehensive research, Islam and its subordinates were explained in anthropological terms. It is more or less offensive to singers who lived in Singapore related to the process of the pilgrimage. Besides, a study from Stokhof (2008) which is still related to the process of migration of Bawean explains the Bawean group in Vietnam. Not like the foreigners in Singapore, they migrated to Vietnam with financial background. However, this study only explains how Bawean people migrated to Singapore in its historical process.

\section{Method}

This study uses historical method to further explore how the Bawean process came and developed in Singapore in the 19 th to 20 th century. The research was conducted starting from heuristics, source 
point, interpretation, and historiography. Primary sources, was obtained from several Singapore newspapers which published in 19th to 20th century. Most of them have been digitalized. Therefore, these sources accessible, besides that books and journals are also used that explain the activities of Baweanese both on Bawean Island and in some of their overseas.

For the activities of migrating Baweanese who have high mobility. Etymologically, the concept of social mobility comes from the word mobilis (Latin) which means to move, and the word social (English), which means society. Thus, social mobility is a movement of people. Referring to the concept of social mobility proposed by Soekanto (1987), social mobility is a movement in social structures, namely certain patterns that govern the organization of a social group. Based on the above description, it can be concluded with a simple understanding that social mobility is a change in the position or status of individuals or groups of individuals in society, both vertically and horizontally. Mobility carried out by Baweanese was inseparable from the various aspects of its driving force, so it is also interesting to see how the development of Baweanese after arriving in Singapore as a form of mobility.

This form of mobility practiced by Baweanese is known as wandering. According to Tsuyoshi Kato $(2005,4)$, wandering is defined as an effort to leave home to seek for wealth, knowledge, and fame. Overseas activities carried out by Baweanese have a variety of objectives, such as economic, religious, and others. This assistance tradition was not only owned by Baweanese people because many tribes/ethnicities in Indonesia have overseas traditions, one of which was the Minangkabau people. For the Minangkabau people, wandering was activity which cannot be separated from their lives. The Minangkabau people adhere to a matrilineal culture system which causes the position of men to be marginalized so that to prove their success, wanderers become one of the main choices made (Leake 2009, 15). The wandering activity can also be categorized into the concept of migration. According to Said Rusli in Sholikin et al. (2016, 143), migration is a form of permanent or relatively permanent displacement of a person or group (within a certain period) by taking a certain minimum distance, moving from one geographical unit to another.

\section{Baweanese Migration to Overseas}

Baweanese people have a desire to migrate since a very long time ago. It is not known for certain when the tradition of wandering among the Bawean people was carried out because there was no official record explaining it. Official records regarding the diaspora of Bawean are included in Singapore. Recorded in the Cencus of the Colony of Singapore conducted by the Singapore government at that time the Bawean people were there in 1849, with a total of about 763 both men and women, thus there are indications that Bawean people had existed in Singapore before 1849. One of the cultures that exist in the Baweanese was the wandering culture. In addition to finding new jobs in the destination area, they also reasoned to look for experience. The tradition of wandering for Baweanese has become an integral part of their lifestyle. For Baweanese, migration to overseas have been introduced since childhood (Sholikin et al. 2016, 144). This was what causes the Baweanese people do diaspora in various regions not only in Indonesia but also in other countries. After succeeding with the work done, many Baweanese then returned to their hometown. On overseas land, many Baweanese work odd jobs. Although, it didnot experiened by everyone, in many cases, Baweanese became drivers, construction workers, and the rest were became traders. Baweanese who carry out trade activities can be found in several cities in Java, such as Surabaya, Gresik, Banyumas, Kedu, Madiun, and Kediri (Dobbin 1991, 119).

One of the overseas destinations for Baweanese is Singapore. Since Singapore was appointed as a British trading post in the Eastern Region in 1819 by Sir Thomas Stamford Raffles, the island has attracted many migrants from India, China, and migrants from the archipelago, such as Bugis and Java (Solihin 2014, 248). People from Bawean are also interested in visiting Singapore. Apart from economic motives, there were also religious motif in which Singapore was used as a transit point for later continuing the pilgrimage to Arab land.In the initial period before the emergence of steamships as a mode of transportation for overseas travel, sailboats were used as the main 
transportation. Hence, it took quite a long time to reach their destination, approxiamately for weeks or even months depending on which area was intended. In the early phase of overseas (around the 19th century), generally, migrants were confined to men. This was related to the travel distance, so it required stamina and physically healthy. Some of the areas that became the destination of nomads from Bawean were Singapore, Malaysia, and even Brunei Darussalam (Haryono 2016, 180). In Singapore, Baweanese even make villages.

Many of the Baweanese then chose to settle in Singapore because they felt comfortable. Most of the Baweanese who settled were young people. Even so, not a few Baweanese returned to their hometowns because their initial purpose was only to earn money that was used to come back to their hometown. Baweanese who return to their hometowns with better economic conditions are an inspiration for relatives on Bawean Island. This creates a new mindset among the Baweanese that Singapore was an easy place to earn money and has a high salary compared to Bawean Island which still depended primarily on the agricultural sector or pandanus woven. Besides, during the Dutch East Indies colonial period, they preferred to go to Singapore to avoid tax levies in that era and avoid being obliged to become soldiers during the Japanese occupation era.

Primordial relations between fellow Baweanese make it difficult for those who migrate for the first time without any difficulty in terms of residence. The relationship was shown when there was a new nomad from Bawean, they will be accommodated in a house that was commonly named Pondok. They were not only limited to being accommodated in a hut but also seeking for a job. As a social bond formed on the same basis and interests, a Pondok was led by a chairman called "Lurah Pondok" or cottage leader. The concept of the lurah was a form of leadership tradition on Bawean Island, a village led by a lurah who was responsible for social affairs and welfare (Solihin 2014, 250).

\section{Arrival Period of Baweanese People}

No one knows exactly when Baweanese first came to Singapore. A search of the Baweanese living in Singapore could only be found clearly when there was a population census conducted by the Singapore government in 1849. At that time, for the first time, they were officially called by the name Boyanese. There are several differences here regarding the classification of Boyan women and men in Singapore. In The Singapore Free Press and Mercantile Advertiser newspaper dated February 1, 1850, there were 763 people with a ratio of 733 men and 30 women. While in the book entitled One Hundred Years of Singapore written by Walter Makepeace and published in 1991, it was mentioned that men of Boyan numbered 720 while women were 43 (Makepeace 1991). In 1824, a census conducted by the Singapore government for the first time was very possible to assume that Baweanese people were included in the Bugis category. At the 1824 census, the number of Bugis was 1,925 (Buckley 1902, 154). Culturally, Baweanese people have similarities with the Bugis. Besides, on several occasions, it can also be seen that the Baweanese people also became the crew of the Bugis ship.

Looking at some of the news published in the Singapore newspaper, many people from the archipelago were engaging in Singapore relations. In November 4, 1851, several people from the Bajo tribe sailed to Singapore. The Bajo brought his wife and children along with several items to sell, such as rice, turtles and sea cucumbers. In addition to Bajo, Baweanese have also made the same trip using sailboats (The Singapore Free Press and Mercantile Advertiser November 21 1856, 2).

Half of the Baweanese who were in Singapore in 1850 worked in the plantation sector and the rest were laborers. In the early days, the majority of Baweanese who came to Singapore were adult men and only a few of them took their wives along with them. This was a natural thing to do considering the insufficient means of transportation used as a means of mobilization. Before the steamship became a new trend in the shipping world, the Baweanese only used sailboats as their main transportation. The reason many Bawean men do not take their wives with them is that the obligation to earn a living is the responsibility of men, while women are only tasked with taking care of the house and looking after their parents. Besides, many Boyans came to Singapore 
independently, as young unmarried men seeking experience and learning to live independently. They did not depend on family (Spaan 1994, 96).

The wave of migration carried out by the Baweanese which were quite large occurred between 1901-1911. This was caused by the policy made by the Dutch East Indies colonial government at that time. The Dutch East Indies colonial government implemented an individual tax policy. Every person who lives in an area was required to pay taxes on himself (Rahman and Marsita, "The Baweanese"). In addition to encouragement from the inside, Baweanese went to Singapore for transportation access that has been facilitated since the advent of steamboat transportation as well as the opening of public transportation services for Bawean Island people who will go to Singapore, one of which is the Dutch freight forwarding company, Koninklijke Paketvaart Maatschappij (KPM). Initially, KPM was a ship used to transport goods and was not intended to transport humans. Then, there was a change when KPM opened passenger transportation services held by Palembang nobles who had Kemas which is a traditional title for male aristocrats from Palembang. One of the aristocrats from Palembang who had an important role in the process of the diaspora of Bawean people was Hajj Kemas Djamaludin. In addition to passenger transportation services opened by KPM, some of the same services are opened by Chinese by the name of The Singapore Heap Eng Moh Shipping Company. This company operated at the beginning of the 20th century. Looking at the development of steamships with passenger transportation, companies that provide shipping services from Bawean Island to Singapore wre in line with the growing number of Bawean residents in Singapore from the early to mid of 20th century.

Table 1. The Development of The Baweanese's Population in Singapore

\begin{tabular}{cccc}
\hline Year & Man & Woman & Total \\
\hline 1849 & 720 & 43 & 763 \\
1871 & 1.377 & 257 & 1.634 \\
1881 & 1.504 & 607 & 2.111 \\
1891 & 1.808 & 869 & 2.677 \\
1901 & 1.701 & 1.011 & 2.712 \\
1911 & 3.028 & 2.058 & 5.086 \\
1921 & 3.765 & 2.824 & 6.589 \\
1931 & 5.338 & 4.075 & 9.413 \\
1947 & 8.237 & 7.197 & 15.434 \\
1957 & 11.580 & 10.587 & 22.167 \\
\hline
\end{tabular}

Source: Vredenberg 1991, 94

The emergence of companies engaged in sea transportation, such as KPM and The Singapore Heap Eng Moh Shipping Company, always have their travel routes. KPM travel routes from Singapore that pass Bawean Island are Surabaya, Bawean, Banjarmasin, Pulo Laut, Pasir and Cotie, and back to Singapore. Especially for the Pasir and Cotie areas, it is skipped every four weeks (The Straits Times July 9, 1891). The Singapore Heap Eng Moh Shipping Company has the same route, from Singapore to Surabaya bypassing Bawean Island.

Although the tradition of wandering among the Bawean community was a part of his life, it should also be noted that the first Baweanese who first wandering always used the services of guards (Sholikin 2016, 150). Guards themselves are a term for people who bring the Boyan tribe to be distributed into labor. These guards became important because of their role as a liaison between Baweanese and employment. As explained by Kartono $(2004,127)$, a bodyguard was required to have knowledge, experience, tenacity, agility, must be honest and trustworthy by the community (Sholikin 2016, 150).

One of the people who had a great service to the overseas activities of the Baweanese in the early 1900s was Hadji Kemas Djamaludin together with his family who were agents of the Chinese shipping company and the first KPM in Bawean (Vredenberg 1991, 90) serving the SurabayaBawean-shipping route Banjarmasin-Singapore (Haryono 2016, 173). The entry of Bawean Island 
into the shipping lane was only for transporting passengers. That was because wandering activity among Baweanese began to develop (Utomo 2017, 129).

\section{The Activities of Baweanese in Singapore}

In 1842, Europeans employed many Baweanese for the construction of a racetrack in Singapore. After the arena was built, the Baweanese also worked there as horse trainers from Europeans. When car and motorcycle transportation entered Singapore, the Baweanese turned to become drivers for Europeans. Besides, Baweanese also worked in ports and became gardeners in Singapore. In addition to working as laborers in Singapore, referring to the Singapore Free Press and Mercantile Advertiser newspaper which was published on November 21 in 1856, Baweanese sent rice and some of the plantation products from outside Singapore to sell, they used boats to send goods they got from the outside. In several incidents in a similar newspaper, the Boyanese headed for Singapore with the Bugis. The closeness of the Boyanese and the Bugis has long been established when the British ruled in Singapore, the Bawean took part in the voyage carried out by the Bugis who leaned his ship on the Bawean Island while traveling to Singapore.

During the migration period of Baweanese in Singapore, the average of their lives was intertwined with the communities in the Pondok that they shared. It was undeniable because in Singapore society itself prefers to gather with the same ethnic group and the Boyanese also did the same. This continued until their settlement developed and separated from the cottage to make their own house, but still in the same area. Therefore, their villages in several parts of Singapore were given the name Kampong Boyan.

The existence of Pondok was a form of the cultural identity of the Baweanese in Singapore. Besides functioning as a place to stay, the cottage for Baweanese was also functioned as a territory boundary marker with Kampung Melayu. Lukman Solihin (2014) in his journal mentioned that some things need to be considered about Baweanese people in Singapore, including being a migrant who needs to adapt to local culture and adaptation was very impactful. As a consequence, Baweanese then experience socio-cultural changes, especially after mixing with Malays. The emergence of the term Pondok or commonly called Pondhuk mightbe inspired by the habits of Baweanese who send their children to study religion in Islamic boarding schools (Solihin 2014, 250). In addition to making the hut a form of identification of the Baweanese, they also made a small government structure by appointing someone to be the headman of the hut. The concept of lurah leadership is a leadership tradition such as on Bawean Island, where a village was led by a lurah who is then responsible for his citizens.

When they lived and developed in Singapore, not a few Baweanese experienced problems in Singapore. Some of them were accused by local government authorities of possession of sharp weapons and riots. Moreover, some of Boyan's people were accused of possessing sharp weapons during a raid at a club. Then, 10 people were suspected of being questioned to explain this. One of them named Amat bin Dollah pleaded guilty to using a machete to hurt others (The Singapore Free Press and Mercantile Advertiser January 12 1932, 8)

Acculturation also occurs in Bawean society with its environment in Singapore, because of that the culture they brought from the place of origin changes, one of which was the Boyans began to use and also Malay clothing in their daily lives. In the 1950s, Baweanese people still wore sarong with a combination of Koko clothing, while women wore kebaya sarong and veil. Thus, the environment in Singapore which has diversity become an important part of the changes that occur in a community that resides there, and it also happened to the Boyanese who have lived for a long time in Singapore.

\section{Conclusion}

The overseas activities carried out by Baweanese were a form of their culture. Economic and religious factors became the most important background for Baweanese to conduct overseas. The characteristics of the Bawean region which were not very fertile when used for agricultural activities 
were an important issue why then many Baweanese migrate. Increasing economic needs, but not directly proportional to the process of fulfillment, make Baweanese people choose to migrate. Besides, in the early twentieth century after the advent of the steamship line, religious motives also became the background of the Baweanese people to wander. For the majority of Baweanese who were Muslim, performing Hajj was the goal of some people who went overseas. After earning the money, the money was used for hajj.

At the beginning of its development, the mobility carried out by Baweanese to go to other areas only used sailboats. After the advent of the steamboat, it became an early marker of how massive the Bawean social mobility was. The development of steamships for the Baweanese who migrated to Singapore was a catalyst in the growing Baweanese in Singapore. The initial process of the Baweanese heading to Singapore was still using sailboats and some of them also took part in the Bugis ship which carried out the trade to Singapore. Baweanese in the early days were still undergoing a process of returning to their hometowns, until the early twentieth century, they developed and chose to settle in Singapore. Over time, the Bawean community was recognized as a new ethnic group by the Singapore government and in the 1957 census, the Baweanese had the second-largest mass after the Chinese. The mention of Boyan for Baweanese residing in Singapore originated from the mistakes in the pronunciation of Europeans in Singapore. Europeans have authority over there until Boyan's pronunciation continues to be used to refer to Baweanese. A large number of Bawean migrants to Singapore made the local government make policies related to migration issues.

\section{References}

Buckley, Charles Burton. 1902. An Anecdotal History old Times In Singapore Vol I. Singapore: Fraser \& Neave, Limited.

Dobbine, Christine. 1991. "The Importance Of Minority Characteristics In the Formation Of Busines elites on Java: The Baweanese people Example 1870-1940", Archipel, vol. 41:117-127,. https://doi.org/10.3406/arch.1991.2713

Haryono, Tri Joko Sri. 2016. "Konstruksi Identitas Budaya Bawean”, BioKultur, Vol.V, No.2 (Juli-Desember : 166-184.

Kato, Tsuyoshi. 2005. Adat Minangkabau dan Merantau dalam Perspektif Sejarah. Jakarta: Balai Pustaka.

Leake, Rebeca Soraya. 2009. "Pulau Putri: Kebudayaan Migrasi dan Dampaknya di Pulau Bawean", research for ACICIS, University of Muhammadiyah Malang.

Makepeace, Walter et al., ed. 1991. One Hundred Years of Singapore Vol I. New York: Oxford University Press.

Rahman, Nor-afidah Abd., and Marsita Omar. "The Baweanese People (Boyanese)", accessed August 29, 2018. http://eresources.nlb.gov.sg/infopedia/articles/SIP_1069_2007-0620.html

Sholikin, Muhamad Ihwanus et al. 2016. "Merantau Sebagai Budaya (Eksplorasi Sistem Sosial Masyarakat Pulau Bawean)", Cakrawala Journal, Vol.10 No.2:143-153, December :150.

Soekanto, Soerjono. 1982. Sosiologi Suatu Pengantar. Jakarta: CV Rajawali.

Solihin, Lukman. 2014. "Melayu Di Luar, Boyan di Dalam; Politik Identitas Perantau Bawean Di Singapura”, Jurnal Masyarakat dan Budaya, Vol. 16 (2): 81-102.

Spaan, Ernst. 1994. "Taikongs and Calos: The Role of Middlemen and Brokers in Javanese International Migration”, The International Migration Review, Vol. 28, (1): 93-113.

Stokhof, Malte. 2008. The Baweans of Ho Chi Minh City, PhD Research at Vrije Universiteit in Amsterdam, The Netherlands.

The Singapore Free Press and Mercantile Advertiser, January 12, 1932. Page 8.

The Singapore Free Press and Mercantile Advertiser, November 21, 1856. Page 2.

The Straits Times, July 9, 1891. Page 1.

Utomo, Bambang Budi, ed. 2017.Kemaritiman Nusantara. Jakarta: Yayasan Pustaka Obor. 
Vredenberg, Jacob. 1962. "The Haddj: Some Of Its Features And Functions In Indonesia", Bijdragen tot de Taal-, Land- en Volkenkunde, Deel 118, 1ste Afl., Anthropologica III: 91-154.

Vredenberg, Jacob. 1991. Islam dan Bawean. Jakarta: INIS.

Vredenburg, Jacob. 1964. "Bawean Migrations Some Preliminary Notes", Bijdragen tot de Taal-, Land-en Volkenkunde, Deel 120, 1ste Afl., Anthropologica VI: 109-139. 